\title{
PENGEMBANGAN BUKU AJAR ETIKA PROFESI KEPENDIDIKAN BAGI MAHASISWA PASCASARJANA UNIVERSITAS PGRI ADI BUANA SURABAYA
}

\author{
Hari Karyono \\ Pascasarjana Universitas PGRI Adi Buana Surabaya \\ harikaryana@yahoo.com \\ M. Subandowo \\ Pascasarjana Universitas PGRI Adi Buana Surabaya \\ subanindi@gmail.com
}

\begin{abstract}
Abstrak
Penelitian ini bertujuan untuk mengembangkan buku ajar Etika Profesi Kependidik untuk mahasiswa Program Pascasarjana Universitas PGRI Adi Buana Surabaya. Penelitian ini merupakan penelitian pengembangan, dengan model pengembangan Dick \& Carey. Hasil pengembangan berupa draft buku ajar selanjutnya divalidasi. Proses validasi melibatkan ahli materi Etika Profesi, ahli media pembelajaran, dan praktisi pembelajaran. Hasil pengembangan buku ajar menunjukkan rata-rata hasil validasi sangat valid dan ujicoba berada pada kategori layak digunakan dengan predikat baik. Berdasarkan hasil penelitian disarankan untuk melakukan uji coba buku ajar ini dalam skala yang lebih luas. Terutama mahasiswa kependidikan (calon guru) di luar Universitas PGRI Adi Buana Surabaya.
\end{abstract}

Kata-kata kunci: pengembangan, buku ajar, etika profesi kependidikan.

\section{PENDAHULUAN}

\section{Matakuliah Matakuliah Etika}

Profesi Kependidikan ini membahas hakikat ajaran moral untuk memperoleh orientasi kritis sebagai bekal mahasiswa untuk menumbuhkan pemahaman moral, perasaan moral dan tindakan moral terkait dengan profesi guru dan profesi tenaga kependidikan lainnya. Sesuai dengan Kurikulum Program Pascasarjana Universitas PGRI Adi Buana Surabaya, matakuliah ini diberikan pada mahasiswa Program Magister (S2) Program Studi Teknologi Pendidikan dan mahasiswa Program Magister (S2) Program Studi Pendidikan
Olahraga, Program Pascasarjana, Universitas PGRI Adi Buana Surabaya.

Proses pengembangan buku ajar harus mempertimbangkan berbagai hal, antara lain ketersediaan sumber acuan yang digunakan dalam penyusunan buku ajar, karakteristik pengguna buku ajar, dan tuntutan kurikulum (Depdiknas, 2008). Proses pengembangan buku ajar oleh dosen pengampu matakuliah menyesuaikan dengan tujuan instruksional matakuliah, selanjutnya dosen harus mengumpulkan berbagai informasi dari berbagai sumber pustaka, seperti buku teks, artikel ilmiah, jurnal, dan media massa. Informasi kemudian 
dikemas sesuai dengan kebutuhan mahasiswa, selanjutnya ditata, dikemas, dan ditulis sebagai bahan ajar menggunakan kerangka sistematis (Hasamah, 2015).

Buku ajar mempunyai perbedaan dengan buku teks, buku ajar merupakan bahan atau materi pembelajaran disusun secara sistematis yang digunakan guru dan mahasiswa dalam kegiatan belajar mengajar, sedangkan buku teks merupakan sumber informasi yang disusun dengan struktur dan urutan berdasar bidang ilmu tertentu.

Buku ajar yang digunakan untuk pegangan mahasiswa harus terus diupdate dari segi kurikuler, isi, maupun bahasa agar sesuai dengan perkembangan pengetahuan dan kurikulum yang digunakan. Kurikulum yang sering berganti dalam waktu relatif cepat sebagai konsekuensi kebutuhan dunia pendidikan terhadap manusia sebagai subjek karya, karena itu belum tentu dapat diikuti dengan kecepatan pengadaan buku ajar untuk mahasiswa.

Pemanfaatan sumber belajar mempunyai pengaruh terhadap hasil belajar mahasiswa. Studi pendahuluan yang dilakukan pada semester gasal 2017/2018 di Program Studi S2 Pendidikan Olahraga, Program Pascasarjana, Universitas PGRI Adi Buana Surabaya dalam pemanfaatan buku ajar untuk mata kuliah Etika
Profesi Kependidikan, mahasiswa hanya menggunakan buku teks bidang ilmu tertentu sebagai sumber belajar dengan hasil ketercapaian tujuan pembelajaran yang masih belum optimal, dikarenakan mahasiswa hanya mendapatkan sumber informasi dari buku teks saja. Di samping itu, aktivitas mahasiswa dalam pembelajaran masih kurang aktif. Saat ini, sumber belajar yang digunakan adalah buku teks bidang ilmu tertentu. Oleh karenanya, diperlukan sumber belajar lain yang sesuai dengan materi perkuliahan untuk memperluas wawasan pemahaman dan keterampilan mahasiswa tentang materi pembelajaran Etika Profesi Kependidikan. Dengan wawasan pemahaman dan keterampilan yang luas mahasiswa dapat mengimplementasikan kemampuanya dengan baik dalam proses pembelajaran di kelas.

Di samping itu, mengacu pada kebutuhan pentingnya pembelajaran Etika Profesi Kependidikan berbasis kasus pelanggaran etika di lingkungan sekitar, dosen sebagai pendidik diharapkan mampu mengembangkan bahan ajar berbasis pelanggaran etika di lingkungan sekitar sebagai sumber belajar mahasiswa. Sumber belajar ini penting bagi mahasiswa karena dapat digunakan sebagai rujukan keilmuan. Salah satu tujuan adanya sumber belajar yaitu untuk memudahkan mahasiswa untuk mempelajari 
kompetensi tertentu (Prastowo, 2011; sembilan langkah sebagai berikut: (1) Prasetiyo \& Perwiraningtyas, 2017).

mengenali tujuan pembelajaran,

Berdasarkan analisis kebutuhan melakukan analisis pembelajaran,

di lingkungan Program Pascasarjana mengenali tingkah laku dan ciri-ciri Universitas PGRI Adi Buana Surabaya, diketahui bahwa sampai saat ini belum ada buku ajar yang isinya sesuai dengan deskripsi matakuliah Etika Profesi Kependidikan. Oleh karena sementara ini, dosen dan mahasiswa menggunakan sumber belajar dari handout yang dibuat oleh dosen, dan upload dari internet. Sehingga materi yang dijadikan dalam kegiatan belajar mengajar terpenggalpenggal dan belum menjadi suatu kesatuan yang utuh. Sementara itu, buku teks tentang Etika Profesi Kependidikan yang telah diterbitkan, cakupan materinya belum sesuai dengan Satuan Acara Perkuliahan (SAP) yang telah disusun oleh dosen pengampu matakuliah. Oleh karena itu, perlu dilakukan penelitian dan pengembangan buku ajar matakuliah Etika Profesi Kependikan bagi mahasiswa Program Pascasarjana Universitas PGRI Adi Buana Surabaya.

\section{METODE PENELITIAN}

Model pengembangan yang digunakan dalam pengembangan buku ajar matakuliah Etika Profesi Kependidikan ini adalah model pengembangan Dick \& Carey (2009). Model ini mengarah pada upaya pemecahan masalah belajar dengan prosedur kegiatan yang terdiri atas

pebelajar, (4) merumuskan tujuan perfomansi, yaitu pernyataan khusus tentang apa yang mampu dikerjakan pebelajar setelah mengikuti pelajaran, (5) mengembangkan butir-butir test acuan patokan yang terdiri dari test tingkah laku masukan, pra test, pasca test dan test sambil jalan, (6) mengembangkan strategi pembelajaran yang meliputi kegiatan pra pengajaran, penyajian informasi, latihan dan balikan, pengetesan dan kegiatan-kegiatan lanjutan, (7) memilih dan mengembangkan materi pembelajaran yang meliputi buku petunjuk kerja Mahasiswa Teknologi Pendidikan, Program Pascasarjana Universitas PGRI Adi Buana Surabaya, buku ajar dan test, (8) merancang dan melakukan penilaian formatif. Penilaian formatif yang harus dilakukan adalah : (a) uji ahli isi, (b) uji coba perorangan, (c) uji coba kelompok kecil dan (d) uji coba lapangan, (9) merevisi pembelajaran berdasarkan dan Program Magister (S2) Pendidikan Olahraga, Program Pascasarjana, Universitas PGRI Adi Buana Surabaya.

Jenis data yang digunakan dalam penelitian ini adalah kualitatif dan kuantitatif. Data kualitatif diperoleh dari kritik dan saran dari para validator dan koresponden uji coba. Data kuantitatif diperoleh dari data hasil validasi dari 
para validator dan dari data uji coba skala kecil para mahasiswa. Sedangkan instrument dalam penelitian dan pengembangan ini berupa lembar validasi ahli dan korespondensi uji coba produk.

Analisa data pada penelitian pengembangan buku ajar dilakukan secara deskriptif kualitatif dan kuantitatif (Haryati, 2012). Analisis deskriptif kualitatif digunakan untuk mengolah data dari hasil validasi ahli materi, hasil validasi ahli media pembelajaran, hasil validasi praktisi pembelajaran pengampu matakuliah Etika Profesi Kependidikan dan hasil uji perseorangan, mahasiswa Program Pascasarjana Universitas PGRI Adi Buana Surabaya.

\section{HASIL}

Berdasarkan pelaksanaan penelitian dan pengembangan yang telah dilakukan, maka

\section{Hasil Validasi Ahli Materi}

Proses validasi buku ajar dilakukan oleh ahli materi matakuliah
Etika Profesi Kependidikan Program Pascasarjana Universitas PGRI Adi Buana Surabaya. Buku ajar diberikan kepada ahli materi matakuliah Etika Profesi Kependidikan untuk mendapatkan penilaian dan tanggapan tentang buku ajar yang telah dikembangkan. Data yang diperoleh dari tahap validasi ahli materi berupa penilaian secara kualitatif, penilaian secara kuantitaif, dan saran terhadap buku ajar. Komponen materi yang diukur meliputi kelayakan isi, kelayakan bahasa, dan kelayakan penyajian. Masing-masing komponen memiliki beberapa sub komponen penilaian secara rinci dapat dilihat pada tabel 1 tersebut di bawah ini. Saran yang diperoleh dari ahli materi terhadap buku ajar berbasis penelitian ini adalah: (1) tata kalimat dalam penjelasan materi diperbaiki, penulisan sumber gambar diperbaiki, (3) tatanan cover diperbaiki, dan (4) gambar hendaknya dirujuk dalam teks.

Tabel 1 Data Hasil Validasi Ahli Materi

\begin{tabular}{|l|l|l|r|r|r|l|}
\hline No & Komponen & \multicolumn{1}{|c|}{ Sub Komponen } & $\begin{array}{c}\text { Skor } \\
\text { Total }\end{array}$ & $\begin{array}{c}\text { Skor } \\
\text { Maks }\end{array}$ & \% & Keterangan \\
\hline 1. & Kelayakan isi & $\begin{array}{l}\text { Kesesuaian materi } \\
\text { dengan tujuan } \\
\text { pembelajaran }\end{array}$ & 10 & 12 & 83 & Cukup valid \\
\cline { 3 - 7 } & Keakuratan materi & 11 & 12 & 92 & Sangat valid \\
\cline { 3 - 7 } & Pendukung materi & 14 & 16 & 88 & Sangat valid \\
\hline 2. & $\begin{array}{l}\text { Kelayakan } \\
\text { bahasa }\end{array}$ & $\begin{array}{l}\text { Kesesuaian dengan } \\
\text { perkembangan } \\
\text { mahasiswa }\end{array}$ & 8 & 8 & 100 & Sangat valid \\
\hline
\end{tabular}




\begin{tabular}{|l|l|l|r|r|r|l|}
\hline \multirow{2}{*}{} & & Keterbacaan & 3 & 4 & 75 & Cukup valid \\
\cline { 3 - 7 } & Kelugasan & 7 & 8 & 88 & Sangat valid \\
\cline { 3 - 7 } & Koherensi & 7 & 8 & 88 & Sangat valid \\
\cline { 3 - 7 } & $\begin{array}{l}\text { Kesesuaian kaidah } \\
\text { bahasa }\end{array}$ & 7 & 8 & 88 & Sangat valid \\
\cline { 3 - 7 } & $\begin{array}{l}\text { Penggunaan } \\
\text { istilah/lambang }\end{array}$ & 12 & 12 & 100 & Sangat valid \\
\hline 3. & $\begin{array}{l}\text { Kelayakan } \\
\text { penyajian }\end{array}$ & Teknik penyajian & 10 & 12 & 83 & Cukup valid \\
\cline { 3 - 7 } & Pendukung penyajian & 15 & 16 & 94 & Sangat valid \\
\cline { 3 - 7 } & Kelengkapan penyajian & 18 & 20 & 90 & Sangat valid \\
\hline & Jumlah & $\mathbf{1 2 2}$ & $\mathbf{1 3 6}$ & $\mathbf{9 0}$ & Sangat valid \\
\hline
\end{tabular}

Sumber: data diolah dari lapangan.

Berdasarkan tabel 1 di atas, dapat disimpulkan bahwa berdasarkan validasi ahli materi pembelajaran, dari komponen kelayakan isi setelah dianalisis diperoleh nilai untuk kesesuaian materi dengan tujuan pembelajaran "cukup valid" (83\%), keakuratan materi "sangat valid" (92\%), dan pendukung materi "sangat valid" (88\%). Berdasarkan komponen kelayakan bahasa, dari aspek kesesuaian dengan perkembangan bahasa "sangat valid" (100\%), keterbacaan "cukup valid" (75\%), kelugasan "sangat valid" $(88 \%)$, koherensi "sangat valid" (88\%), kesesuaian kaidah bahasa "sangat valid" $(88 \%)$, dan penggunaan istilah/lambing "sangat valid" (100\%). Sementara itu, untuk komponen kelayakan penyajian, dari aspek teknik penyajian "cukup valid" (83\%), pendukung penyajian "sangat valid" (94\%), dan kelengkapan penyajian "sangat valid" (90\%)". Sedangkan secara keseluruhan data hasil penilaian dari ahli materi pembelajaran terhadap buku ajar Etika Profesi
Kependidikan nilainya adalah 90\% (sangat valid).

\section{Hasil Validasi Ahli Media Pembelajaran}

Proses validasi buku ajar Etika Profesi Kependidikan dilakukan oleh ahli media pembelajaran Program Pascasarjana Universitas PGRI Adi Buana Surabaya. Buku ajar Etika Profesi Kependidikan diberikan kepada ahli media pembelajaran untuk mendapatkan penilaian dan tanggapan tentang buku ajar yang telah dikembangkan. Data yang diperoleh dari tahap validasi ahli media berupa penilaian secara kuantitaif dan penilaian secara kualitatif berupa saran terhadap buku ajar. Komponen yang diukur meliputi kelayakan kegrafikaan dan kelayakan penyajian. Masing-masing komponen memiliki beberapa sub komponen penilaian yang secara rinci dapat dilihat pada tabel 2 berikut di bawah ini. Sedangkan saran yang diperoleh dari ahli media pembeljaran 
terhadap buku ajar berbasis penelitian ini adalah: (1) pemilihan jenis huruf hendaknya memilih jenis huruf yang tegas supaya mudah untuk dibaca, (2) daerah putih pada naskah buku ajar hendaknya dikurangi, dan (3) ukuran dan keterangan gambar hendaknya diperjelas.

Tabel 2 Data Hasil Validasi Ahli Media Pembelajaran

\begin{tabular}{|l|l|l|r|r|r|l|}
\hline No & Komponen & \multicolumn{1}{|c|}{ Sub Komponen } & $\begin{array}{r}\text { Skor } \\
\text { Total }\end{array}$ & $\begin{array}{c}\text { Skor } \\
\text { Maks }\end{array}$ & \% & Keterangan \\
\hline \multirow{2}{*}{1} & \multirow{2}{*}{$\begin{array}{l}\text { Kelayakan } \\
\text { kegrafikaan }\end{array}$} & Ukuran buku & 8 & 8 & 100 & Sangat valid \\
\cline { 3 - 7 } & & Desain cover buku & 65 & 72 & 90 & Sangat valid \\
\cline { 3 - 7 } & & Desain isi buku & 124 & 136 & 91 & Sangat valid \\
\hline \multirow{2}{*}{2.} & \multirow{2}{*}{$\begin{array}{l}\text { Kelayakan } \\
\text { penyajian }\end{array}$} & Teknik penyajian & 11 & 12 & 92 & Sangat valid \\
\cline { 3 - 7 } & & Pendukung penyajian & 14 & 16 & 88 & Sangat valid \\
\cline { 3 - 7 } & Kelengkapan penyajian & 18 & 20 & 90 & Sangat valid \\
\hline & & Jumlah & $\mathbf{2 4 0}$ & $\mathbf{2 6 4}$ & $\mathbf{9 1}$ & Sangat valid \\
\hline
\end{tabular}

Sumber: data diolah dari lapangan.

Berdasarkan tabel 2 di atas, dapat disimpulkan bahwa berdasarkan validasi ahli media pembelajaran, dari komponen kelayakan kegrafikaan setelah dianalisis diperoleh nilai untuk ukuran buku "sangat valid" (100\%), desain cover buku "sangat valid" (90\%), dan desain buku "sangat valid" (91\%). Sementara itu, dari komponen kelayakan penyajian, teknik penyajian "sangat valid" (92\%), pendukung penyajian "sangat valid" $(88 \%)$, dan kelengkapan penyajian "sangat valid" $(90 \%)^{\prime \prime}$. Sedangkan secara keseluruhan data hasil penilaian dari ahli media pembelajaran terhadap buku ajar Etika Profesi Kependidikan nilainya adalah 91\% (sangat valid).

\section{Data Hasil Validasi Praktisi}

\section{Pembelajaran}

Proses validasi buku ajar selanjutnya dilakukan oleh praktisi pembelajaran Universitas PGRI Adi Buana Surabaya. Buku ajar diberikan kepada praktisi pembelajaran untuk mendapatkan penilaian dan tanggapan tentang buku ajar yang telah dikembangkan. Data yang diperoleh dari tahap validasi praktisi pembelajaran berupa penilaian secara kuantitaif dan penilaian secara kualitatif b erupa saran terhadap buku ajar. Komponen yang diukur meliputi meliputi kelayakan isi, kelayakan bahasa, dan kelayakan penyajian. Masing-masing komponen memiliki beberapa sub komponen penilaian yang dapat dilihat pada tabel 3 berikut dibawah ini. Saran yang diperoleh dari praktisi pembelajaran terhadap buku ajar matakuliah Etika 
Profesi Kependidikan ini adalah: (1) Profesi Kependidikan hendaknya lebih istilah tujuan pembelajaran hendaknya diperjelas lagi, dan (3) rangkuman di diganti dengan learning outcomes dan setiap akhir bab hendaknya lebih disesuaikan dengan kurikulum KKNI, diperjelas lagi.

(2) learning outcomes pembelajaran Etika

\section{Tabel 3 Data Hasil Validasi Praktisi Pembelajaran}

\begin{tabular}{|c|c|c|c|c|c|c|}
\hline No & Komponen & Sub Komponen & $\begin{array}{l}\text { Skor } \\
\text { Total }\end{array}$ & $\begin{array}{l}\text { Skor } \\
\text { Maks }\end{array}$ & $\%$ & Keterangan \\
\hline \multirow[t]{6}{*}{1} & \multirow[t]{6}{*}{$\begin{array}{l}\text { Kelayakan } \\
\text { bahasa }\end{array}$} & $\begin{array}{l}\text { Kesesuaian dengan } \\
\text { perkembangan mahasiswa }\end{array}$ & 7 & 8 & 88 & Sangat valid \\
\hline & & Keterbacaan & 3 & 4 & 75 & Cukup valid \\
\hline & & Kelugasan & 7 & 8 & 88 & Sangat valid \\
\hline & & Koherensi & 6 & 8 & 75 & Cukup valid \\
\hline & & Kesesuaian kaidah bahasa & 7 & 8 & 88 & Sangat valid \\
\hline & & $\begin{array}{l}\text { Penggunaan } \\
\text { istilah/lambang }\end{array}$ & 10 & 12 & 83 & Cukup valid \\
\hline \multirow[t]{3}{*}{2.} & \multirow[t]{3}{*}{ Kelayakan isi } & $\begin{array}{l}\text { Kesesuaian materi dengan } \\
\text { tujuan pembelajaran }\end{array}$ & 10 & 12 & 83 & Cukup valid \\
\hline & & Keakuratan materi & 12 & 16 & 75 & Cukup valid \\
\hline & & Pendukung materi & 10 & 12 & 83 & Cukup valid \\
\hline \multirow[t]{4}{*}{3.} & \multirow{3}{*}{$\begin{array}{l}\text { Kelayakan } \\
\text { penyajian }\end{array}$} & Teknik penyajian & 10 & 12 & 83 & Cukup valid \\
\hline & & Pendukung penyajian & 12 & 16 & 75 & Cukup valid \\
\hline & & Kelengkapan penyajian & 15 & 20 & 75 & Cukup valid \\
\hline & & Jumlah & 109 & 136 & 80 & Cukup valid \\
\hline
\end{tabular}

Sumber: data diolah dari lapangan.

Berdasarkan tabel 3 di atas, dapat disimpulkan bahwa berdasarkan data hasil validasi praktisi pembelajaran, dari komponen kelayakan bahasa, setelah dianalisis diperoleh nilai sub komponen kesesuaian dengan perkembangan bahasa "cukup valid" (75\%), sub komponen keterbacaan "cukup valid" (75\%), sub komponen kelugasan "cukup valid" (75\%), sub komponen koherensi "cukup valid" (75\%), sub komponen kesesuaian kaidah bahasa "cukup valid" $(75 \%)$, dan sub komponen penggunaan istilah/lambing "cukup valid" (75\%). Dari komponen kelayakan isi untuk sub komponen kesesuaian materi dengan tujuan pembelajaran "cukup valid" (83\%), keakuratan materi "sangat valid" (92\%), dan pendukung materi "sangat valid" (88\%). Selanjutnya, dari komponen kelayakan penyajian, untuk sub komponen teknik penyajian "cukup valid" (83\%), sub komponependukung penyajian "sangat valid" (75\%), dan sub komponen kelengkapan penyajian "sangat valid" (75\%)". Sedangkan secara 
keseluruhan data hasil penilaian dari ahli media pembelajaran terhadap buku ajar Etika Profesi Kependidikan nilainya adalah 91\% (sangat valid).

\section{Data Hasil Uji Perseorangan}

Buku ajar selanjutnya diujicobakan secara perseorangan kepada 20 mahasiswa S2 Program Pascasarjana Universitas PGRI Adi Buana Surabaya. untuk mendapatkan penilaian dan tanggapan tentang buku ajar materi matakuliah Etika Profesi Kependidikan yang telah dikembangkan. Data yang diperoleh dari tahap uji coba perseorangan berupa penilaian secara kuantitaif dan penilaian secara kualitatif berupa saran terhadap buku ajar. Komponen yang diukur meliputi meliputi aspek kejelasan buku ajar materi matakuliah Etika Profesi Kependidikan, pengaruh terhadap peserta didik, dan kemungkinan yang dapat dilihat pada tabel 4. Saran yang diperoleh dari praktisi pembelajaran terhadap buku ajar berbasis penelitian ini adalah: (1) rangkuman perlu diperbaiki, (2) ukuran gambar perlu diperbaiki, keterpaduan warna dan tulisan pada halaman bab perlu diperbaiki, (4) warna cover perlu diperbaiki, dan (5) gambar hasil penelitian perlu ditambah.

Tabel 4 Hasil Uji Perseorangan

\begin{tabular}{|c|l|c|c|c|l|}
\hline No & \multicolumn{1}{|c|}{ Aspek } & $\begin{array}{c}\text { Skor } \\
\text { Total }\end{array}$ & $\begin{array}{c}\text { Skor } \\
\text { Maks }\end{array}$ & \%oterangan & Ken \\
\hline 1 & Kejelasan buku ajar & 328 & 396 & 82.83 & Cukup valid \\
\hline 2 & Pengaruh teradap peserta didik & 135 & 180 & 75.00 & Cukup valid \\
\hline 3 & Kemungkinan (feasilibility) & 139 & 180 & 77.22 & Cukup valid \\
\hline & Jumlah & $\mathbf{6 0 2}$ & $\mathbf{7 5 6}$ & $\mathbf{7 9 , 6 3}$ & Cukup valid \\
\hline
\end{tabular}

Sumber: data diolah dari lapangan.

Berdasarkan tabel 4 di atas, dapat disimpulkan bahwa dari hasil uji perseorangan mahasiswa Program Pasacasarjana Universitas PGRI Adi Buana Surabaya, diketahui aspek kejelasan buku ajar memperoleh nilai 82,93\% (cukup valid), aspek pengaruh teradap peserta didik memperoleh nilai $75,00 \%$ (cukup valid), dan aspek kemungkinan (feasilibility) memperoleh nilai $77,22 \%$ (cukup valid). Sedangkan secara keseluruhan data hasil uji perseorangan terhadap buku ajar Etika Profesi Kependidikan nilainya adalah $79,63 \%$ (cukup valid).

\section{PEMBAHASAN}

Buku ajar merupakan buku yang digunakan oleh dosen sebagai sumber acuan dalam pelaksanaan proses pembelajaran bagi mahasiswanya (Pascasarjana UB, 2011; Ngadimun, 2013; 
Pratama, Amin \& Suarsini, 2016). dikeluhkan mahasiswa dalam Disamping itu, buku ajar dapat memahami isi buku (Astuti, dkk., 2012). digunakan pendidik dan peserta ddik guna meningkatkan kompetensinya. Hasil validasi ahli terhadap Mahasiswa dipandang sebagai subjek belajar yang perlu dilibatkan secara aktif dalam proses pembelajaran, dan dosen hanyalah seorang fasilitator yang membimbing dan mengkoordinasikan kegiatan belajar mahasiswa. Bahan ajar berupa buku ajar ini dapat memudahkan proses pembelajaran dan memiliki daya tarik serta mampu memotivasi mahasiswa untuk lebih aktif dalam proses pembelajaran, lebih interaktif, dan lebih kritis dalam menjawab masalah-masalah yang berhubungan dengan materi Etika Profesi Kependidikan (Ramansyah, 2013).

Bahan ajar yang berkualitas adalah bahan ajar yang memiliki komponen isi yang materinya dapat digunakan untuk menjawab permasalahan mahasiswa dalam mencapai tujuan pembelajaran (Depdiknas, 2008; Pratama, Amin \& Suarsini, 2016). Sementara ini, dalam kenyataannya kebanyakan para dosen cenderung menggunakan teks book dari penerbit sebagai bahan mengajar di kelas. Hal tersebut memang tidak salah, namun perlu diingat bahwa isi atau materi dalam teks book dari penerbit belum tentu cocok dengan kondisi lingkungan dan kebutuhan mahasiswa. Disamping itu, penggunaan bahasa asing dalam teks book terkadang buku ajar materi matakuliah Etika Profesi Kependidikan diperoleh nilai sebesar 93\% dan termasuk dalam kategori sangat valid. Nilai tersebut menunjukkan bahwa buku ajar Etika Profesi Kependidikan berbasis penelitian dapat digunakan dalam pembelajaran dengan sedikit revisi di beberapa bagian buku. Masukan yang diperoleh dari ahli materi terhadap buku ajar ini adalah dari komponen kelayakan bahasa dan kelayakan penyajian. Komponen kelayakan bahasa yang mendapat sorotan lebih adalah dari ketepatan tata bahasa yang digunakan yang masih banyak ditemukan kata penghubung di depan kalimat. Saran yang digunakan dalam perbaikan buku ajar berbasis penelitian ini adalah terutama pada perbaikan tata bahasa yang digunakan dan penggunaan rujukan gambar dalam penjabaran materi. Perbaikan tata bahasa bertujuan untuk mempermudah pemahaman mahasiswa ketika membaca buku ajar Etika Profesi Kependidikan berbasis penelitian ini. Hal tersebut sesuai dengan syarat sebuah buku supaya dapat membantu proses berpikir dan belajar mandiri peserta didik, yaitu buku memiliki tingkat keterbacaan tinggi, menarik minat dan memikat (Muljono, 2007). 
Hasil validasi selanjutnya adalah hasil validasi dari ahli media. Hasil validasi dari ahli media diperoleh nilai cukup tinggi, yaitu sebesar 92\% dan termasuk dalam kategori sangat valid. Hal tersebut menandakan bahwa buku ajar Etika Profesi Kependidikan berbasis penelitian ini dapat digunakan dalam pembelajaran namun masih membutuhkan sedikit revisi meskipun nilai validitasnya cukup tinggi. Saran yang diberikan oleh ahli media terhadap buku ajar sebagian besar tentang komponen kelayakan kegrafikaan buku ajar. Keseluruhan saran dari ahli media bertujuan untuk mencapai syarat kegrafikaan buku teks yang baik, yaitu tersaji dalam tampilan yang menarik dan menggambarkan ciri khas buku pelajaran, kemudahan untuk dibaca dan digunakan, dan kualitas fisik buku yang baik (Muljono, 2007).

Hasil validasi berikutnya adalah dari praktisi pembelajaran matakuliah Etika Profesi Kependidikan. Hasil validasi terhadap buku ajar Etika Profesi Kependidikan menghasilkan nilai sebesar $74 \%$ sehingga masuk dalam kategori cukup valid. Hal tersebut menandakan bahwa buku ajar masih memerlukan revisi supaya dapat digunakan dalam pembelajaran Etika Profesi Kependidikan. Saran yang diperoleh dari praktisi pembelajaran terutama adalah pada bagian tujuan pembelajaran. Praktisi pembelajaran selaku dosen pengampu matakuliah Etika Profesi Kependidikan di Program Pasacasarjana, Universitas PGRI Adi Buana Surabaya berpendapat bahwa hendaknya mengganti istilah tujuan pembelajaran menjadi learning outcomes. Selain itu, tata bahasa learning comes yang disusun harus mencerminkan kurikulum matakuliah Etika Profesi Kependidikan yang berbasis KKNI. Hal tersebut sesuai dengan pernyataan Prastowo (2012) yang menyatakan bahwa buku ajar atau buku teks pelajaran merupakan buku yang dikembangkan dari kurikulum yang berlaku, sehingga salah satu fungsi buku ajar adalah sebagai alat bantu pendidik dalam melaksanakan kurikulum.

$$
\text { Tahap selanjutnya yaitu }
$$
dilakukan uji coba secara perseorangan oleh 20 mahasiswa S2 Program Studi Teknologi Pendidikan dan S2 Pendidikan Olahraga yang telah mengikuti perkuliahan Etika Profesi Kependidikan. Aspek yang dinilai dalam validasi perseorangan ini adalah aspek kejelasan buku ajar, aspek pengaruh terhadap pengguna, dan aspek kemungkinan atau feasibility. Hasil validasi perseorangan mencapai nilai $81 \%$ dan termasuk dalam kategori cukup valid. Hal tersebut menandakan bahwa buku ajar Etika Profesi Kependidikan berbasis penelitian juga memerlukan perbaikan di beberapa komponen supaya dapat digunakan dalam pembelajaran Etika Profesi 
Kependidikan. Berdasarkan hasil uji cobaditemukan beberapa kata yang sulit dipahami oleh mahasiswa. Revisi yang dilakukan yatiu mengganti katakata sulit tersebut dengan kata-kata yang lebih familiar dan mudah dipahami. Hal tersebut sesuai dengan pernyatan dari Muljono (2007) yang menyatakan bahwa buku ajar hendaknya berisi informasi, pesan, dan pengetahuan yang dituangkan dalam bentuk tertulis yang dapat dikomunikasikan kepada pembaca secara logis, mudah diterima sesuai dengan tahapan perkembangan kognitif pembaca.

Keseluruhan saran dari ahli media bertujuan untuk mencapai syarat kegrafikaan buku teks yang baik, yaitu teruji dalam tampilan yang menarik dan menggambarkan ciri khas buku pelajaran, kemudahan untuk dibaca dan digunakan, dan kualitas fisik buku yang baik (Muljono, 2007; Fadilah, Amin \& Lestari, 2016).

Berdasarkan hasil penelitian dan pengembangan menunjukkan bahwa sampul buku telah memberikan pengaruh yang signifikan terhadap keputusan konsumen dalam pembelian buku (Awaliyah, 2008; Fadilah, Amin \& Lestari, 2016). Di samping itu, dikemukakan oleh Hernowo (2004) bahwa desain sampul buku yang ditata apik dan proporsional, lebih memberikan efek daripada desain buku yang hanya terdiri atas teks dan tidak proporsional.

Hasil produk pengembangan berupa buku ajar yang telah direvisi berdasarkan komnetar dan saran validator bertujuan untuk perbaikan buku ajar, sehingga pemakaian buku ajar menjadi lebih efisien, efektif dan komunikatif kepada pembaca, dengan tetap memperhatikan tujuan penyusunan buku ajar (Fidiastuti \& Rozana, 2016; Prasetiyo \& Perwiraningtyas, 2017).

Lebih lanjut dapat dikemukakan, bahwa kelebihan produk yang dikembangkan adalah isi materi buku ajar Etika Profesi Kependidikan ini telah sesuai dengan kompetensi yang harus dicapai oleh para mahasiswa. Indikator kompetensi menjadi acuan dalam pengembangan materi buku. Selain itu, buku ajar ini dikembangkan berbasis kasus-kasus pelanggaran etika profesi yang terjadi di lapangan, sehingga diharapkan mahasiswa lebih memahami permasalahan di lingkungan dan mengkaitkan konsep dengan kehidupan sehari-hari.

Kekurangan terkait dengan produk yang dikembangkan adalah buku ajar Etika Profesi Kependidikan dikembangkan sampai pada tahap uji coba lapangan dan masih belum diuji keefektifannya pada kelas sesungguhnya. Buku ajar ini spesifik membahas terkait dengan materi Etika 
Profesi Kependidikan, belum mencakup etika profesi secara umum.

Berdasarkan hasil penelitian Syamsi (2013) \& Anggela (2013) pembelajaran menggunakan buku ajar dapat memudahkan proses pembelajaran, sehingga membantu pencapaian ketuntasan kompetensi peserta didik. Hal ini disebabkan karena buku ajar mudah dipahami oleh peserta didik pada respon mahasiswa pada tingkat keterbacaan terhadap buku ajar tergolong sangat baik.

\section{SIMPULAN}

Penelitian dan pengembangan ini menghasilkan buku ajar Etika Profesi Kependidikan. Buku ajar ini telah tervalidasi oleh ahli materi, ahli media dan pembelajaran, serta telah melalui proses uji coba terbatas yakni uji perorangan dan uji coba skala sekelompok kecil, sehinggga sesuai dengan kebutuhan materi dan karakteristik mahasiswa. Kelebihan dari buku ajar ini adalah isi materi buku ajar Etika Profesi Kependidikan ini telah sesuai dengan kompetensi yang harus dicapai oleh para mahasiswa Program Pascasarjana Universitas PGRI Adi Buana Surabaya. Sedangkan kekurangan terkait dengan produk yang dikembangkan adalah buku ajar Etika Profesi Kependidikan pada tahap uji coba lapangan masih diujikan pada kelas yang terbatas, yaitu hanya dilaksanakan pada mahasiswa S2 Program Studi Teknologi Pendidikan dan mahasiswa
S2 Program Studi Pendidikan Olah Raga Program Pascasarjana Universitas PGRI Adi Buana Surabaya.

\section{DAFTAR PUSTAKA}

Anggela, M. 2013. Pengembangan Buku Ajar Bermuatan Nilai-nilai Karakter pada Materi Usaha dan Momentym untuk Pembelajaran Fisika Siswa Kelas XI SMA. Pillar of Physics Education, Vol. 1, 63-70.

Astuti, E.P., ismadi, Mulyani D. \& Bariyah, K. 2012. Pengembangan Bahan Ajar Matakuliah Dasar-Dasar Desain Berbasis Kearifan Lokl bagi Mahasiswa Pendidikan Seni Rupa. Yogyakarta: Universitas Negeri Yogyakarta

Awaliyah, T. 2008. Pengaruh Desain Sampul terhadap Keputusan Pembelian Buku di Toko Gramedia Ambarukmo Plaza Yogyakarta. Tesis tidak diterbitkan. Yogyakarta: UIN Sunan Kalijaga.

Depdiknas. 2008. Panduan Pengembanga Bahan Ajar. Jakarta, Indonesia: Direktorat Pembinaan Sekolah Menengah Atas, Depdiknas.

Dick, W., Carey, L. \& Carey, J.O. 2009. The Systematic Design of Instruction. Seventh Edition. USA: Pearson.

Fadilah, R.E., Amin, M. \& Lestari, U. 2016. Pengembangan Buku ajar Etika Profesi Kependidikan Berbasis Penelitian untuk Mahasiswa S1 Pendidikan Biologi 
Universitas PGRI Adi Buana Surabaya. Jurnal Pendidikan: Teori, Penelitian, dan Pengembangan. Volume 1 Nomor 6 Bulan Juni Tahun 2016, halaman 1104-1109. Fidiastuti, H.R. \& Rozana, K.M. 2016. Developing Modul of

Microbiology Subject Through Biodegradation by Using the Potencial of Indigen Bacteria. Jurnal Pendidikan Biologi Indonesia, 2 (2), 125-132.

Haryati, S. 2012. Research and Development (R\&D) sebagai Salah Satu Model Penelitian dalam Bidang Pendidikan. FKIPUTM, 37 (1): 11-26.

Hasamah, Rochman, F. \& Utomo, H.

2015. Development of Enrichment Book of Animal Ecology Based on Collembola Community Structure Research Throughout Watershed Brantas Upstream of Batu City. Prosiding Seminar Nasional Pendidikan Biologi 2015, Univeritas Muhammadiyah Malang, Jawa Timur.

Hernowo. 2004. Langkah Mudah Membuat Buku yang Menggugah. Bandung: MLC.

Muljono. 2007. Buletin Badan Standar Nasional Pendidikan. Volume II (1), 2007.

Ngadimun, D.H. 2013. Penyusunan Buku Ajar. Bandar Lampung: disampaikan pada Pelatihan Penyusunan Buku Ajar bagi
Dosen FISIP Universitas Lampung.

Pascasarjana UB. 2011. Pedoman Umum Penulisan Bahan Ajar-PDKLP. Malang: Pascasarjana, Universitas Brawijaya.

Prasetiyo, N.A. \& Perwiraningtyas, P. 2017. Pengembangan Buku Ajar Berbasis Lingkungan Hidup pada Matakuliah Biologi di Universitas Tribhuwana Tunggadewi. Jurnal Pendidikan Biologi Indonesia, Volume 3 Nomor 1 Tahun 2017, halaman 19-27.

Prastowo, A. 2011. Panduan Kreatif Membuat Bahan Ajar Inovatif. Yogyakarta, Indonesia: Diva Press.

Pratama, M.A., Amin, M, Suarsini, E. 2016. Pengembangan Buku Ajar Matakuliah Bioteknologi di Universitas Jember. Jurnal Pendidikan: Teori, Penelitian, dan Pengembangan, Volume 1 Nomor 10 Bulan Oktober Tahun 2016, halaman 1987-1992.

Priyanto, S.H. 2012. Kriteria Buku Ajar. Disampaikan dalam Worksop Penulisan Buku Ajar Dosen Kopertis VI, Semarang Jawa Tengah.

Ramansyah, W. 2013. Pengembangan Bahan Ajar Mata Kuliah Strategi Pembelajaran untuk Mahasiswa Pendidikan Guru Sekolah Dasar. Madura Bangkalan. Jurnal Widyagogik, Volume 1 Nomor 1. 
Syamsi, K. 2013. Pengembangan Model

Buku Ajar Membaca Berdasarkan

Pendekatan Proses bagi Siswa SMP Yogyakarta. Jurnal Cakrawala Pendidikan, Th XXXII No.1. 